\title{
Evaluation of Toxicity of Maura Reduced Graphene Oxide using in vitro Systems
}

Reshma S Cherian ${ }^{1 \#}$, Sreejith $\mathbf{R}^{2 *}$, Syama $\mathbf{S}^{1}$, Sruthi $\mathbf{S}^{1}$, Gayathri $\mathbf{V}^{1}$, Toru Maekawa ${ }^{2}$, Sakthikumar $\mathrm{D}^{2 *}$ and Mohanan $\mathrm{PV}^{1 *}$

${ }^{1}$ Toxicology Division, Biomedical Technology Wing, Sree Chitra Tirunal Institute for Medical Sciences and Technology, Thiruvananthapuram 695012 , Kerala, India

${ }^{2}$ Bio-Nano Electronics Research Centre, Toyo University, Saitama, Kawagoe, Japan

\#These authors contributed equally

\begin{abstract}
The intriguing properties of graphene has paved way for many potential biomedical applications like drug delivery, tissue engineered scaffold, bio sensing and so on. Here, we report the interaction of Maura reduced graphene oxide (MRGO) with the peripheral blood mononuclear cells (PBMNCs), as there is a likelihood of graphene coming in contact with the blood through intentional or accidental exposure. MRGO was synthesized by reducing graphene oxide using Halomonas Maura and autoclaved subsequently to prevent microbial contamination. It was characterized by TEM, AFM and FITR. Initial cytotoxicity was conducted in L929 cells to get the dose response. Oxidative stress potential, effect on proliferative capacity, genotoxicity and induction of apoptosis in PBMNCs treated with MRGO were assessed. MRGO elicited a dose dependent ROS generation which promoted apoptosis in PBMNCs. Proliferation of these cells were also found to be hindered. However, MRGO did not induce genotoxicity and generation of reactive nitrogen species. In conclusion MRGO shows a dose dependent toxicity in cells, generating ROS, inducing apoptosis and affecting proliferation, which may be due to the loss of exopolysaccharide coating due to autoclaving. This study raises a serious concern regarding the in vivo biomedical application of MRGO, where IV and IP are the main routes of exposure. Further evaluation is required regarding the interaction of autoclaved MRGO with the blood cells.
\end{abstract}

Keywords: Graphene; Peripheral blood mononuclear cells; Nanotoxicity; White blood cells; Microbial graphene synthesis

\section{Introduction}

In the recent years, a lot of engineered nanomaterials are being fabricated, whose applications are being investigated.This has fetched the attention of government and scientific community regarding the safety of these nanomaterials [1]. Graphene, an allotrope of carbon, has come into the limelight after ground breaking research conducted by Novoselov et al. [2]. They were awarded the Nobel Prize in physics in 2010. Graphene is made up of a single layer of $\mathrm{Sp}^{2}$ bonded carbon atom, arranged in a honeycomb lattice network. It has numerous unique physical properties like excellent electronic conductivity [3,4], superior mechanical strength [5], thermal conductivity [6], optical properties $[7,8]$ and many more. These intriguing properties of graphene makes it suitable for electronic and biomedical applications like electrodes, transmitters, biosensing and cellular imaging, tissue engineering, targeted drug/gene delivery, photothermal therapy and so on $[9,10]$.

Of particular interest is the biomedical application aspect of graphene. Yang et al. [11] studied the high uptake of nanographene by tumor and its efficient destruction through photothermal therapy. Nanographene has strong NIR optical absorption ability which was utilized for eradication of tumor via NIR laser irradiation. It has a large surface area and ability to adsorb numerous small molecules via $\pi-\pi$ interactions [12]. It has also been shown to preferentially adsorb to single stranded DNA and RNA [12]. These properties are being utilized for drug delivery and bio sensing, respectively. Graphene, having superior mechanical strength and thermal properties, is also being considered in tissue engineering arena as reinforcement for scaffolds to increase its overall physical property $[13,14]$. These biological applications of nanographene require it to be biocompatible with the biological system. Adverse reaction to any material in vivo can lead to harmful, even fatal consequences and the initial aim of utilizing the material for the benefit of mankind will have an ironic ending. Hence, for any biomedical application, especially in vivo, great care must be taken to ensure that the toxicity of the nanomaterials is well characterized and understood.
There are relatively few studies available on the toxicity of graphene. Zhang et al. [15] showed the cytotoxic effect of nanographene platelets on the human osteosarcoma cell (MG63). It was seen that, at a lower concentration, there was no obvious cytotoxicity. However, delayed cell cycle, induction of apoptosis and increased concentrations of TNF- $\alpha$ were noticed. Zhang et al. [16] compared the cytotoxicity level of carbon nanotubes (CNT) with graphene in PC-12 neural cells. They found that cytotoxicity and induction of oxidative stress was shape dependent, with CNT more toxic than nanographene. It was shown by Liao et al. [17] that aggregated graphene sheets showed less hemolytic activity of RBCs when compared to graphene oxide.

With limited literature available on the toxicity and increasing concern regarding the safety of graphene, it has become pertinent to scrutinize more conclusively, the interaction of graphene with the biological system. For biomedical applications, the interaction of graphene with blood cells should be analyzed, as intraperitoneal (IP) and intravenous administrations (IV) are the major routes of exposure for these applications. Also any accidental exposure to graphene can also lead to its entry into the blood stream. In light of this, an effort was made here to investigate the toxicity of autoclaved MRGO with peripheral blood mononuclear cells (PBMNCs).

*Corresponding authors: Mohanan PV, Toxicology Division, Biomedical Technology Wing, Sree Chitra Tirunal Institute for Medical Sciences and Technology, Thiruvananthapuram 695 012, Kerala, India, Tel: 09446542702; Fax: 91-471-2341814; E-mail: mohanpv10@gmail.com

Sakthikumar D, Bio-Nano Electronics Research Centre, Toyo University, Saitama, Kawagoe, Japan, E-mail: drsakthi@gmail.com

Received April 14, 2014; Accepted May 15, 2014; Published May 20, 2014

Citation: Cherian RS, Sreejith R, Syama S, Sruthi S, Gayathri V, et al. (2014) Evaluation of Toxicity of Maura Reduced Graphene Oxide using In vitro Systems. J Nanomed Nanotechnol 5: 200. doi:10.4172/2157-7439.1000200

Copyright: (c) 2014 Cherian RS, et al. This is an open-access article distributed under the terms of the Creative Commons Attribution License, which permits unrestricted use, distribution, and reproduction in any medium, provided the original author and source are credited. 


\section{Materials and Methods}

\section{Experimental animals}

Swiss Albino mice were procured from the Division of Laboratory Animal Sciences of Biomedical technology wing, SCTIMST, Trivandrum, India. They were maintained in a $12 \mathrm{~h}$ light and dark cycle at controlled environmental conditions of temperature $\left(22 \pm 2^{\circ} \mathrm{C}\right)$ and humidity (30-70\%). Commercially available feed and filtered water were provided ad libitum. The experiments were performed after obtaining prior approval from the Institutional Animal Ethics Committee and as per the Committee for the Purpose of Control and Supervision of Experiments on Animals (CPCSEA) guidelines.

\section{Synthesis and characterization of MRGO}

Moderately halophilic bacterium, Halomonasmaura (ATCC 700995) was purchased from ATCC and was propagated in MY medium as mentioned elsewhere $[18,19]$.The medium was supplemented with various concentrations of graphene oxide $(\mathrm{GO})$ for bacterial reduction. GO was synthesized via modified Hummer's method using graphite powder (Ito Kokuen co., Ltd, Japan) [20]. So obtained GO was brownish in color and showed a uniform suspension. Sterilized MY medium was incorporated with different concentrations of GO. Subsequently, the culture bottles were flushed with ultrapure $\mathrm{N}_{2}$ and inoculated with $H$. maura. Bacterial reduction of GO takes place at $32^{\circ} \mathrm{C}$ in dark conditions and it was kept under incubation for 3-7 days. Rate of reduction depends upon the concentration of the GO added to the medium [21]. Black precipitate formed was the bacterially reduced GO, which was subjected to various purification steps and characterized using TEM and AFM. The MRGO was subsequently autoclaved to ensure there was no bacterial contamination. Comparison between autoclaved and non autoclaved MRGO was done using FTIR to characterize any change in MRGO due to the same. H. Maura reduced graphene oxide (MRGO) after characterization, was used for various biological and toxicological studies.

TEM images were taken using JEM- 2200FS, JEOL under a voltage of $200 \mathrm{Kv}$. AFM images were recorded using MFP-3D-CF, Asylum Research under non-contact AC-Air topographic mode with a scan rate of $1.0 \mathrm{~Hz}$, using a $\mathrm{V}$ - shaped tapping tip. FTIR was also performed using Thermo Scientific, NICOLET iS50 ATR-FT-IR. Infrared spectra were recorded in the region of $4000-400 \mathrm{~cm}^{-1}$. Interactions of various functional groups and chemical bonds present in MRGO during the spontaneous bacterial reduction of GO can be found using ATR-FTIR. Similarly, the changes which took place during the autoclaving process of MRGO were also monitored using the same. Three samples were analyzed using ATR-FTIR- (1) Graphene Oxide (GO); (2) AutoclavedMRGO; (3) Non-Autoclaved- MRGO

\section{Preparing MRGO solution}

To prepare stock solution, appropriate amount of MRGO was dissolved in dimethyl sulphoxide (DMSO). The final concentration of DMSO in culture was kept below $1 \%$ to avoid toxic effect of DMSO. Prior to use, the particles were autoclaved to remove any contaminating bacteria that could affect the culture.

\section{Cytotoxicity}

Cytotoxicity MRGO in L929 cells were done using MTT (3-(4,5-Dimethylthiazol-2-yl)-2,5-diphenyltetrazolium bromide)assay [22]. The MTT assay relies on the activity of mitochondrial succinate dehydrogenase, of the live cell, in reducing yellow MTT to purple formazan [23]. This assay provides a measure of cell viability after being exposed to a substance. Briefly, L929 cell were seeded in 96 well plates at a density of 20,000 cells per well. Varying concentration of MRGO $(25,50,100,200,300,400,500$ and $600 \mu \mathrm{g} / \mathrm{ml})$ was added after $24 \mathrm{~h}$ of incubation. Following an incubation of $24 \mathrm{~h}$ with MRGO, the supernatant was removed and MTT was added and kept for $4 \mathrm{~h}$. After discarding the supernatant, the formazan crystals were solubilised with DMSO for 15 mins and then read at $540 \mathrm{~nm}$ spectrophotometrically (ELx 808 ultra microplate reader, Bio- Tek instruments, USA). Triplicate of each sample was done and untreated cells served as negative control. A DMSO control was also kept.

\section{Isolation of Peripheral blood mononuclear cells (PBMNCs)}

Pooled blood was collected from healthy human volunteers (with informed consent) and mixed with heparin. PBMNCs were isolated using histopaque (Sigma, USA) at 400g for 30 minutes. Buffy layer was collected and washed twice with PBS and resuspended in RPMI 1640 (Hi Media, India) supplemented with 10\% FBS.

\section{ROS generation}

ROS generation in MRGO treated PBMNCs were assayed using DCFH-DA (2'7'- dicholoroflorescien acetate), a non fluorescent, cell permeate dye. DCFH-DA is converted to fluorescent DCF by the free radicals generated in the cell during oxidative stress. This can be monitored by using fluorescent spectrophotometer. The isolated cells were treated with DCFH-DA according to the protocol of Benedetti et al. [24]. Concisely, cells were incubated with DCFH-DA (Invitrogen, USA) for 30 minutes. The supernatant was discarded and different concentrations of MRGO $(100,300$ and $600 \mu \mathrm{g} / \mathrm{ml})$ were added. As the initial ROS production is being assessed, cells were incubated with MRGO for $4 \mathrm{~h}$ only. After the period, fluorescence was read with excitation wavelength at $450 \mathrm{~nm}$ and emission wavelength at 535 $\mathrm{nm}$ using Plate Chameleon ${ }^{\mathrm{TM}} \mathrm{V}$ (Hidex, Finland). $100 \mu \mathrm{M}$ Hydrogen peroxide $\left(\mathrm{H}_{2} \mathrm{O}_{2}\right)$ served as positive control and untreated cells served as negative control.

\section{Nitrosative stress}

Production of Nitric oxide (NO) by inducible nitric oxide synthase (iNOS) was analyzed. Auto-oxidation of NO, results in the production of Nitrite. This can be measured by a colourimetric assay (Griess reagent) [25]. PBMNCs were isolated and 50,000 cells per well were seeded in a 96 well plate and kept for $24 \mathrm{~h}$. MRGO was added in varying concentration $(100,300$ and $600 \mu \mathrm{g} / \mathrm{ml})$ to the culture and incubated for $24 \mathrm{~h}$. Cells were pelleted and supernatant from PBMNC culture was incubated with equal volume of Griess reagent at RT for 10 minutes. Absorbance was measured at $540 \mathrm{~nm}$ (ELx 808 iu ultra microplate reader, Bio-Tek instruments, USA). The concentration of nitrite in the sample was determined from sodium nitrite standard curve.

\section{Annexin V/Propidium Iodide Live dead assay}

To determine induction of apoptosis in PBMNCs, cells were incubated with varying concentrations of MRGO $(100,300$ and $600 \mu \mathrm{g} /$ $\mathrm{ml}$ ) for $24 \mathrm{~h}$ and then analyzed by FACS. For FACS analysis, apoptotic cells were detected by staining with Annexin $\mathrm{V}$ and propidium iodide using Alexa Flour 488 Annexin V/Dead cell apoptosis kit (Invitrogen, USA). In brief, PBMNCs were washed twice in PBS and resuspended in $50 \mu \mathrm{l}$ of annexin binding buffer (ABB). Annexin $\mathrm{V}(5 \mu \mathrm{l})$ and $1 \mu \mathrm{l}$ propidium iodide $(100 \mu \mathrm{g} / \mathrm{ml})$ was added and samples were incubated in dark for 15 minutes before FACS analysis.

\section{Spleenocyte proliferation assay}

Proliferation of MRGO treated spleenic lymphocytes (spleenocytes) 


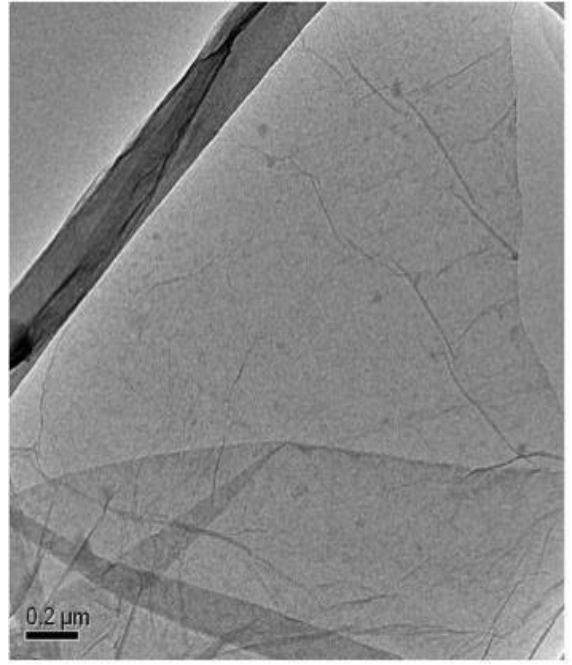

a

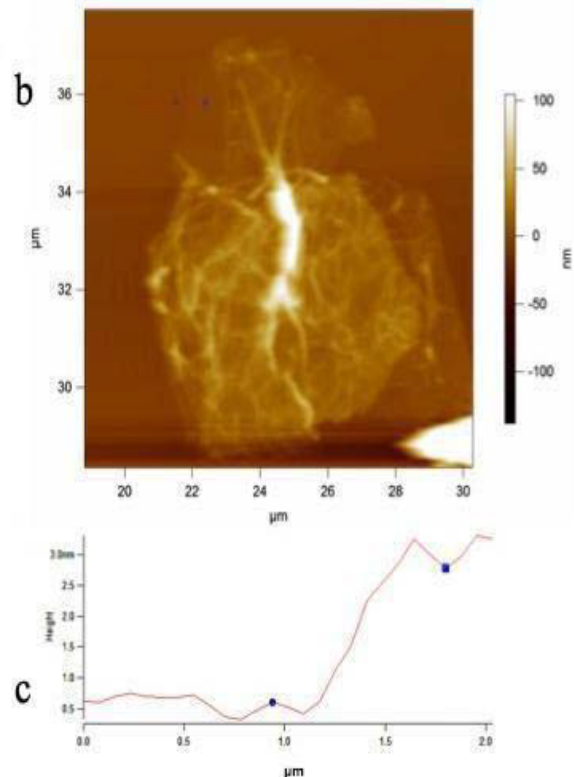

$\mu \mathrm{m}$

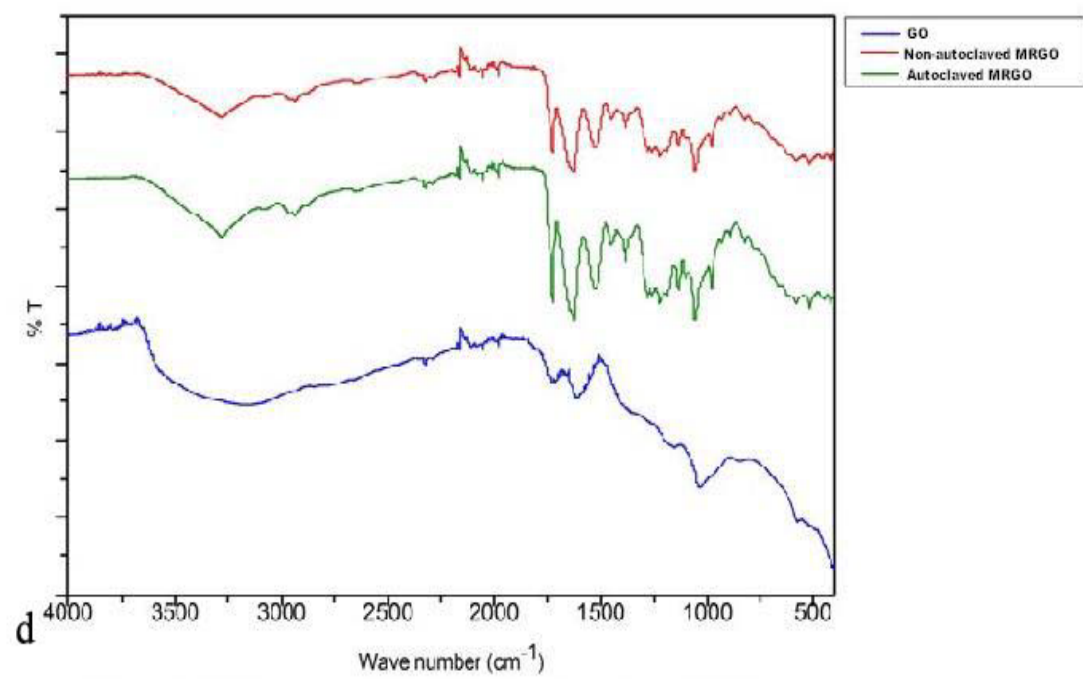

Figure 1: Characterization of MRGO. a) TEM image of MRGO; b) AFM image of MRGO; c) Height retrace graph showing the cross sectional thickness of MRGO; d) FTIR spectra of GO, MRGO and autoclaved MRGO.

were assessed by estimating the incorporation of $\left[{ }^{3} \mathrm{H}\right]$ thymidine. Spleenocytes from the spleen of Swiss Albino mice were isolated using histopaque and cultured in RPMI 1640 supplemented with 10\% FBS. Cells were seeded onto 96 well plates at a cell density of $2 \times 10^{5}$ cells per well and kept in $37^{\circ} \mathrm{C}$ at $5 \% \mathrm{CO}_{2}$. MRGO $(100,300$ and $600 \mu \mathrm{g} / \mathrm{ml})$ was added on the $24^{\text {th }}$ hour of culture. At the $48^{\text {th }} \mathrm{h}, 0.5 \mu \mathrm{Ci}$ of $\left[{ }^{3} \mathrm{H}\right]$ thymidine was added per well. Cells were harvested at $72 \mathrm{~h}$ and radioactivity was measured in cpm using scintillation counter (Hidex, Finland). Data is reported as mean cpm of triplicate samples.

\section{Chromosomal aberration}

Chromosomal aberration assay was followed as per Vijayalakshmi et al. [26]. Heparinized, pooled blood was collected from healthy human volunteers (with informed consent) by venipuncture. $500 \mu \mathrm{l}$ of blood was cultured in $4.5 \mathrm{~mL}$ of PB-Max ${ }^{\mathrm{TM}}$ karyotyping media (Gibco, USA).
100 and $600 \mu \mathrm{g}$ of MRGO was added to the culture on the $48^{\text {th }}$ hour. Colchicine $(1 \mu \mathrm{g} / \mathrm{ml})$ (Sigma, USA) was added one and half hour before $72 \mathrm{~h}$. The cells were harvested by centrifugation. The pellet was treated for $15 \mathrm{mins}$ with warm $0.56 \% \mathrm{KCl}$ solution and centrifuged for $5 \mathrm{mins}$ at $2500 \mathrm{rpm}$. The supernatant was discarded and the pellet was further fixed with chilled Methanol: Acetic acid (3:1). The pellet was dropped onto clean glass slides and stained with Giemsa. 50 metaphases were scored using an automated microscope with Metafer software (Carl Ziess, Germany). Mitomycin C $(1 \mu \mathrm{g} / \mathrm{ml})$ served as positive control whereas untreated cells were taken as control.

\section{Statistical analysis}

All experiments were repeated thrice and all data are presented as the mean with the standard deviation (mean \pm SD) except for chromosomal aberration assay. For chromosomal aberration assay 


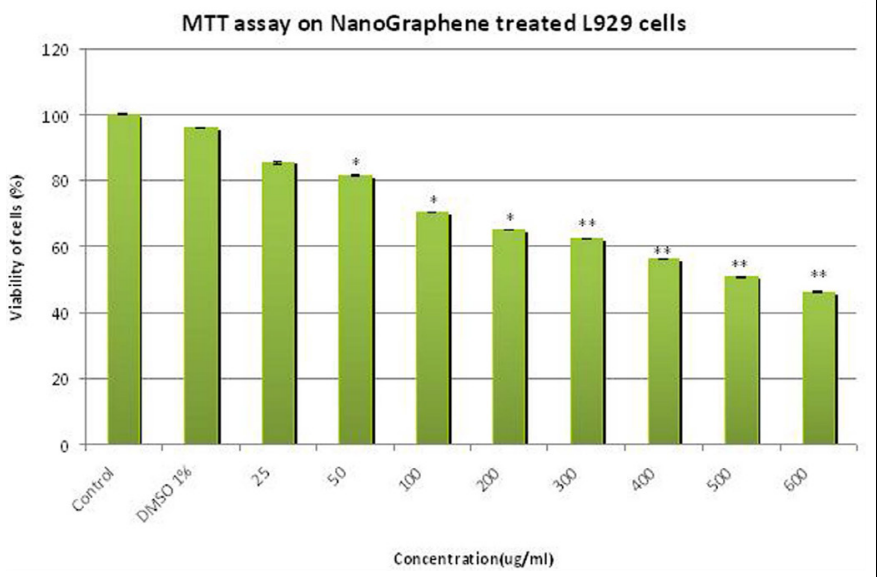

Figure 2: Cytotoxicity of autoclaved MRGO using MTT assay in treated L929 fibroblast cells. ${ }^{*} \mathrm{p} \leq 0.05 ;{ }^{* *} \mathrm{p} \leq 0.005$
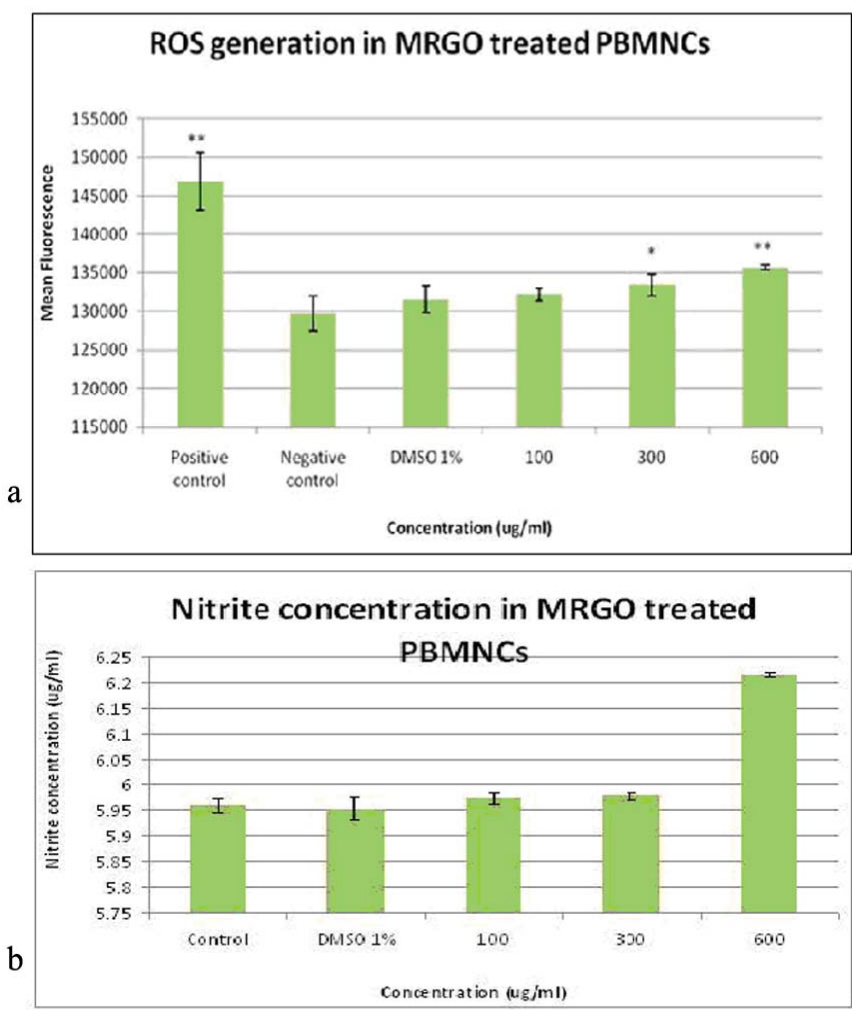

Figure 3: Oxidative stress potential of MRGO. a) ROS generation in PBMNCs treated with autoclaved MRGO. ${ }^{*} \mathrm{p} \leq 0.05 ;{ }^{* *} \mathrm{p} \leq 0.005$; b) Concentration of Nitrite in supernantant of PBMNCs culture treated with autoclaved MRGO.

mean with standard error (mean $\pm \mathrm{SE}$ ) was used to present data. Significance has been calculated using Student's t-test. ${ }^{*}$ denotes a statistical significance ( $\mathrm{p}$ value ${ }^{*} \leq 0.05$ and ${ }^{* *} \leq 0.005$ ) with respect to control.

\section{Results}

\section{Characterization of MRGO}

TEM image of MRGO is shown in Figure 1a. It is clear from the image obtained that MRGO consist of various layers ranging from single to multilayer thicknesses. AFM image of the MRGO is shown in Figure 1b. The cross sectional view of the MRGO (Figure 1c) shows that the average thickness of the MRGO sheets is $\sim 2.7 \mathrm{~nm}$. FTIR spectra of GO (Figure 1d) show a comparatively stronger vibration at $1030 \mathrm{~cm}^{-1}$ corresponding to the $\mathrm{C}-\mathrm{O}$ bonding. Similarly, $\mathrm{C}=\mathrm{C}$ and $\mathrm{C}=\mathrm{O}$ vibrations were detected at $1612 \mathrm{~cm}^{-1}$ and $1722 \mathrm{~cm}^{-1}$ respectively. FTIR spectra of autoclaved and non- autoclaved MRGO reveal that there are no observable chemical changes occurring due to bond breaking with in the MRGO samples on autoclaving. It is evident from the figure that the FTIR spectra of MRGO both before and after the autoclaving process hold similar vibrations.

\section{Cytotoxicity assay}

Results from MTT assay shows a concentration dependent decrease in L929 cell viability (Figure 2). It was seen that up to $80 \%$ of cells were viable at a concentration of $50 \mu \mathrm{g} / \mathrm{ml}$, which was statistically significant $(\mathrm{p}<0.05)$. However, there was a significant loss of cell viability, with only $50 \%$ viability at a concentration of $500 \mu \mathrm{g} / \mathrm{ml}$ and $46 \%$ at $600 \mu \mathrm{g} / \mathrm{ml}$ ( $\mathrm{p}<0.005)$. Hence it was found that the LC50 of autoclaved MRGO fell within the range of $500 \mu \mathrm{g} / \mathrm{ml}$ and $600 \mu \mathrm{g} / \mathrm{ml}$. Viability of cells treated with DMSO (1\%) was comparable with that of control and was not significant.

\section{ROS generation}

To determine whether exposure to MRGO resulted in oxidative stress in PBMNCs, ROS generation was determined. Fluorescence emitted by the conversion of DCFH-DA to DCF due to internal ROS production is shown in Figure 3a. ROS generation was comparable with control in both DMSO control as well at $100 \mu \mathrm{g} / \mathrm{ml}$ MRGO treated PBMNCs. A significant increase in ROS was seen at 300 and $600 \mu \mathrm{g} /$ $\mathrm{ml}$ MRGO $(300 \mu \mathrm{g} / \mathrm{ml}-133429 \pm 1357.25$ and $600 \mu \mathrm{g} / \mathrm{ml}-135692.5$ $\pm 309.006)$ treated cells when compared to the control (129724.33 \pm 2289.517).

\section{Nitrosative stress}

Increased concentration of $\mathrm{NO}$ can result in the formation of Reactive Nitrogen Species (RNS), which can be deleterious to the cell and can cause nitrosative stress. NO production by activation of inducible nitric oxide synthase (iNOS) in PBMNCs was indirectly measured by estimating the concentration of nitrite in the supernatant. From the results shown in Figure 3b, there is a slight raise in nitrite with increase in MRGO concentration but it was found to be statistically insignificant (Control - $5.958 \pm 0.013$ and $600 \mu \mathrm{g} / \mathrm{ml}$ of MRGO - 6.214 $\pm 0.004)$. From this, it is clear that ROS is the major contributor of oxidative stress.

\section{Annexin V/Propidium Iodide Live dead assay}

To check whether the increase in ROS by MRGO causes apoptosis, presence of Annexin V was determined by FACS, as it is an apoptotic biomarker. The data from the live dead assay (Figure $4 \mathrm{a}-4 \mathrm{e}$ ) indicated that only a small percentage of cells were undergoing apoptosis (early apoptosis) at higher concentrations. From Figure $4 \mathrm{f}$ we understand that there was a dose dependent increase (0.4-1.3\% with respect to control) in the percentage of Apototic/ necrotic (Annexin V and PI- positive). Moreover, necrotic cell (PI-positive) were infrequent suggesting that MRGO induced death was mainly due to apoptosis.

\section{Spleenocyte proliferation assay}

From the live/dead assay, it was clear that apoptosis occurred at 

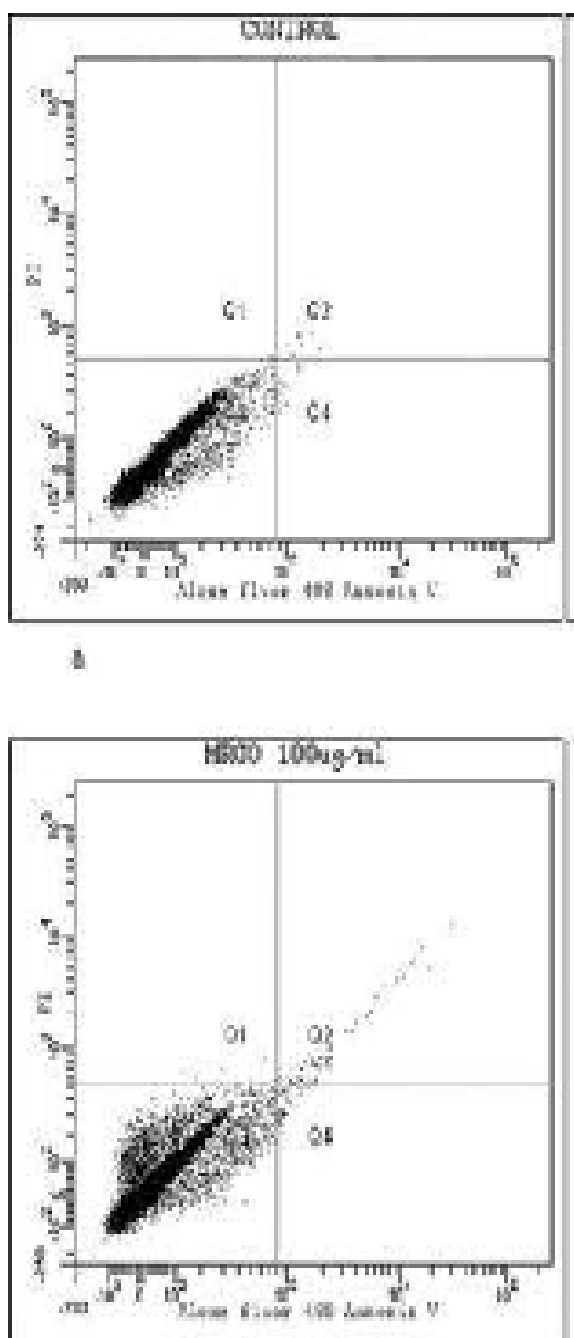

c

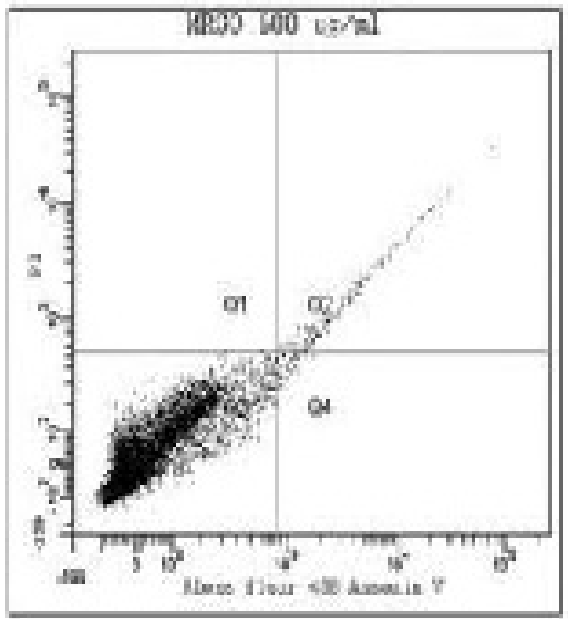

$\forall$

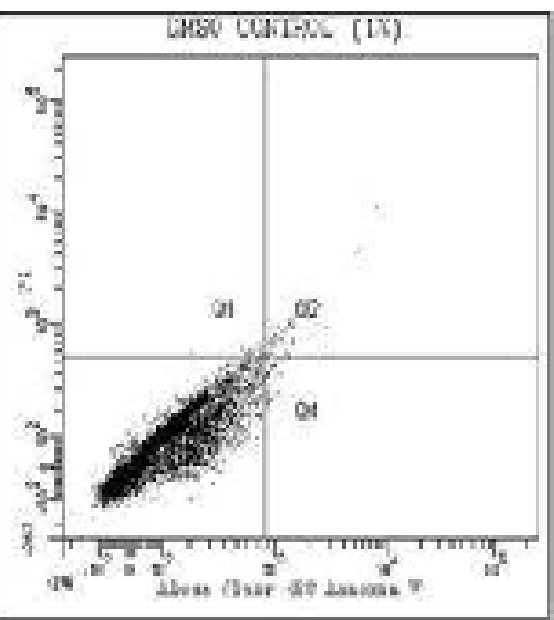

b

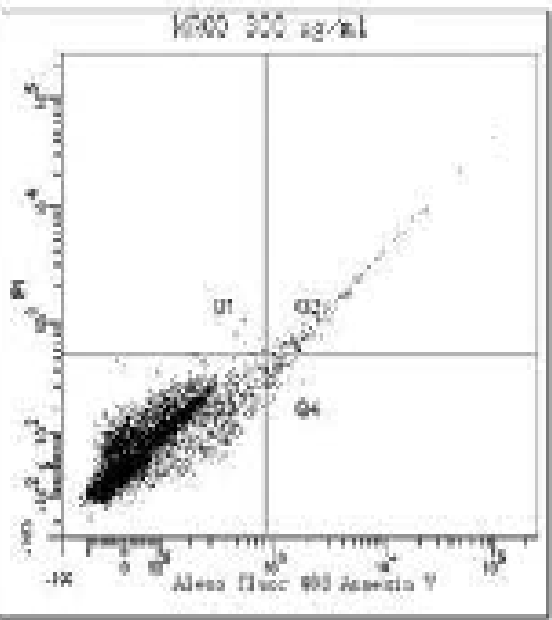

d

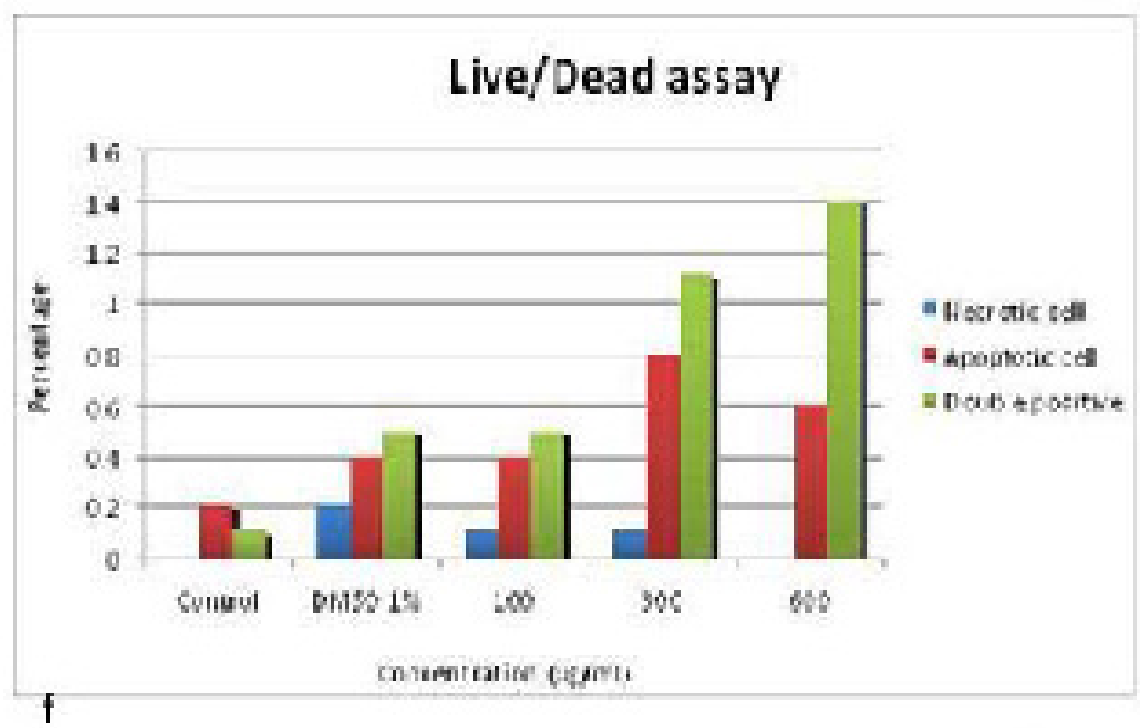

Figure 4: Live/Dead assay using PBMNCs. a) control; b) DMSO 1\%; c) d) e) $100 \mu \mathrm{g} / \mathrm{ml}, 300 \mu \mathrm{g} / \mathrm{ml}$ and $600 \mu \mathrm{g} / \mathrm{ml}$ of autoclaved MRGO respectively; f) Percentage of autoclaved MRGO treated PBMNCs undergoing apoptosis/necrosis. 


\section{Spleenocyte proliferation assay}

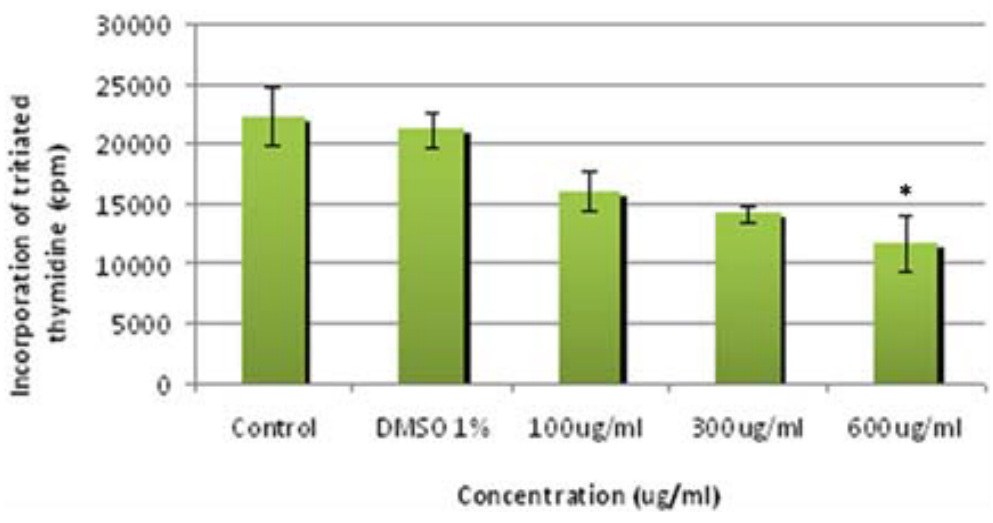

Figure 5: $\left[{ }^{3} \mathrm{H}\right]$ thymidine assay showing proliferation of MRGO treated spleenocytes.

\begin{tabular}{|c|c|c|c|c|c|}
\hline Concentration & Chromosome break (\%) & Chromosome gap (\%) & Chromatid break (\%) & Chromatid Gap (\%) & Other aberration (\%) \\
\hline Control & 0 & 0 & 0 & $0.029 \pm 0.029$ \\
\hline DMSO 1\% & 0 & 0 & $0.087 \pm 0.043$ & $0.022 \pm 0.031$ \\
\hline Positive control & 0 & 0 & $1.333 \pm 0.038^{*}$ & $0.696 \pm 0.066^{*}$ \\
\hline MRGO $(100 \mu \mathrm{g} / \mathrm{ml})$ & 0 & 0 & 0 & $0.014 \pm 0.015$ \\
\hline MRGO $(600 \mu \mathrm{g} / \mathrm{ml})$ & 0 & $0.014 \pm 0.246$ & $0.246 \pm 0.077$ & 0.015 \\
\hline
\end{tabular}

Table 1: Percentage of chromosomal aberration in MRGO treated PBMNCs. * indicates a p value $\leq 0.05$ which was considered significant.

a lower rate. In order to check whether the decrease in viability was the consequence of slower proliferation rate, spleenic lymphocyte proliferation was analyzed. Proliferation of spleenic lymphocytes was found to be affected, in a dose dependent manner, in cells exposed to MRGO. From Figure 5, it is evident that there was a significant decrease in proliferation of the spleenocytes. At $100 \mu \mathrm{g} / \mathrm{ml}$, there was a marked decrease in incorporation of $\left[{ }^{3} \mathrm{H}\right]$ thymidine $(15987.33 \pm 1611.75)$ when compared to control $(22283 \pm 2396.20)$, indicating the decrease in proliferation of the treated cells. It was also seen that the proliferation rate of the spleenocytes was reduced by half at $600 \mu \mathrm{g} / \mathrm{ml}(11581 \pm$ 2341.37). Proliferation rate of DMSO treated cells were comparable with that of the control.

\section{Chromosomal aberration}

As autoclaved MRGO resulted in a decreased proliferation of spleenic lymphocytes, analysis of aberration of chromosome was done, as DNA damage can result in cell cycle arrest at the check points. Results of chromosomal aberration are shown in Table 1 and Figure 6a-e. Chromatid breaks $(0.246 \pm 0.077)$ and chromosome gap $(0.014$ $\pm 0.246)$ were seen at higher concentration of MRGO $(600 \mu \mathrm{g} / \mathrm{ml})$ but were not statistically significant when compared to control. Chromatid gaps were also seen at both lower $(100 \mu \mathrm{g} / \mathrm{ml}-0.014 \pm 0.015)$ and higher concentration $(600 \mu \mathrm{g} / \mathrm{ml}-0.087 \pm 0.066)$ but again were not significant in comparison to control. However, it was interesting to note that, MRGO has a significant role in reduction of proliferation of the PBMNCs as evident from the Figure 7 showing mitotic index (Control $-4.033 \pm 0.088$ and $600 \mu \mathrm{g} / \mathrm{ml}$ MRGO- $1.333 \pm 0.241$ ). Mitotic index represents the percentage of cells in metaphase per 1000 cells. Even though DMSO control treated cells showed chromatid breaks and gaps, they remained insignificant when compared to control as opposed to the mitomycin $\mathrm{C}$ treated cells.

\section{Discussion}

Graphene nanomaterials are gaining increasing prominence over the recent years for their unique physico-chemical properties. Numerous studies have been undertaken for tapping into these properties for nano-electronics as well as biomedical applications like bio-imaging, bio-sensing, drug delivery etc. As the common route of exposure of the particle for such applications involve IP or IV administration, the blood cells becomes susceptible to any potent damage that can be caused by the particle. So it is required to fully understand the interaction of a particle with the different cellular components of blood before in vivo applications. This study mainly focuses on the interaction of MRGO with the peripheral blood mononuclear cells.

In this study, microbial reduction of GO by Halmonasmaura was employed as the method of MRGO synthesis. The conventional method of graphene synthesis involves employing high temperature, release of toxic and unstable gases [18], using highly toxic chemical agents like hydrazine hydrate for reduction. Industrial and biomedical applications demand the need for safer and non-toxic alternative routes for synthesis of graphene. Hence this environmental friendly approach was chosen for synthesis of graphene. As microorganisms were involved in synthesis, the particle was autoclaved prior use to ensure that the culture remained contamination free. For biomedical purposes, it is important to ensure that no microbial contamination will be there as it could cause adverse immunological responses to the material Complete characterization of MRGO particle has been previously done by our group [18] and concurrent results were obtained in this study as well. Moreover the autoclaved and non autoclaved MRGO show similar vibration in the FTIR spectra which indicated that MRGO remained unchanged during autoclaving.

From the cytotoxicity assay, a clear concentration dependent 

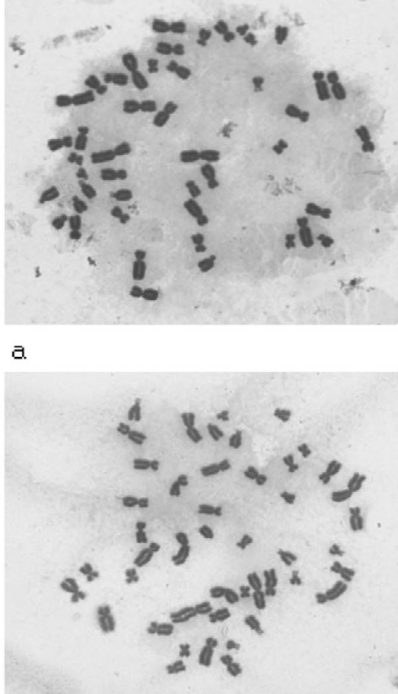

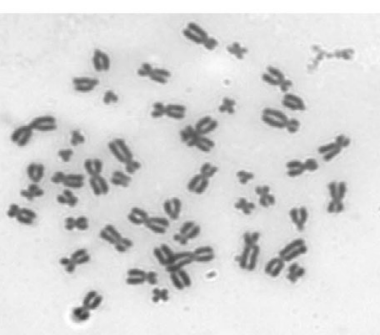

$\mathrm{b}$

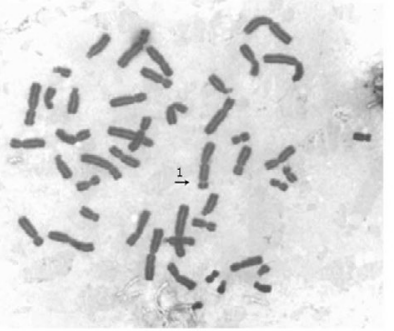

d

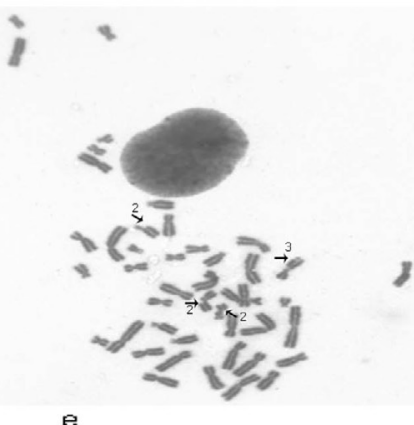

e

Figure 6: Chromosomal aberration assay using PBMNCs (100X magnification) a) control, b) DMSO $1 \%$, c) $100 \mu \mathrm{g} / \mathrm{ml}$ autoclaved MRGO, d) $600 \mu \mathrm{g} / \mathrm{ml}$ autoclaved MRGO where chromosome gap can be seen (1) and e) positive control Mitomycin C where chromatid break (2) and chromatid gap (3) are seen.

\section{Mito tic Index of MRGO treated PBMNCs}

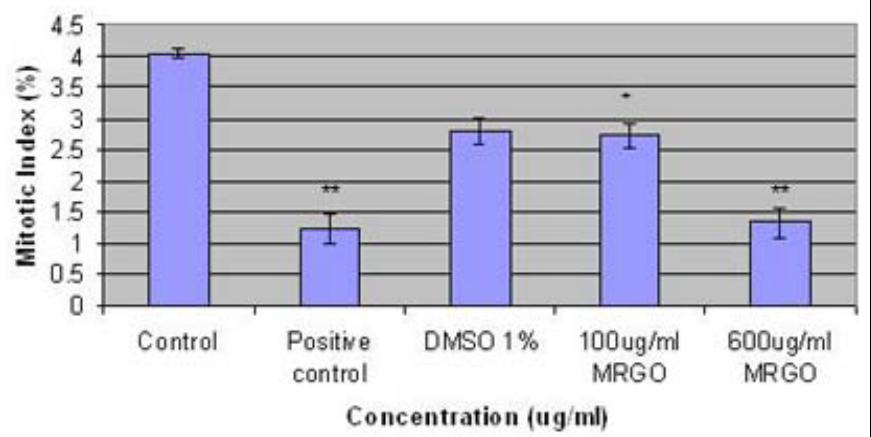

Figure 7: Mitotic index in MRGO treated PBMNCs. " $p \leq 0.05 ;{ }^{* *} p \leq 0.005$.

decline in cell viability was observed in L929 cell treated with autoclaved MRGO. This implies that the particle impairs the metabolic activity of the cells. From the previous study by Raveendran et al. [18], it is seen that the non autoclaved MRGO showed an increased proliferation rate for L929 cells, due to presence of bacterial exopolysaccharide (mauran) coating. Though, mauran is a stable polysaccharide, autoclaving the MRGO would have altered the biological properties of the same. Hence this could explain the contradictory results obtained in the study leading to decreased viability. L929 cells were used here to compare with the previous study and also to identify the dose response to autoclaved MRGO. From this assay, doses of 100,300 and $600 \mu \mathrm{g} / \mathrm{ml}$ were selected throughout the study so as to understand whether the same outcome can be seen in the PBMNCs as well. Not only is that, doses at this level are normally administered for various in vivo applications.

Oxidative and nitrosative stress are one of the major mechanisms of toxicity of nanoparticles [27-30]. Oxidative stress occurs due to excess production of ROS and insufficient antioxidant defence mechanism. Whereas excess NO, produced by inducible nitric oxide synthase (iNOS), results in RNS formation. Both ROS and RNS reacts with various biological molecules resulting in detrimental effects to the cell causing lipid peroxidation, DNA base modification, protein modification and regulation of enzyme activity [31,32]. ROS production was evident in the present study following $4 \mathrm{~h}$ incubation. This agrees with the previous reports, where graphene induced ROS generation in PC-12 cells [16]. Reports by Chang et al. [33] and Horvath et al. [34] also proved that graphene oxide induces ROS production in A549 cell and cells of the luminal surface of lungs respectively. Despite ROS generation, MRGO failed to stimulate the macrophages significantly, resulting in an insignificant NO formation. Hence it was found that PBMNCs treated with autoclaved MRGO followed ROS dependent toxicity pathway. ROS can trigger apoptotic events in the cell by causing mitochondrial membrane depolarization which leads to the release of cytochrome $c$, a central event for programmed cell death or apoptosis [35,36]. Various studies prove that carbon nanoparticles can induce apoptosis $[37,38]$. Earlier study on pristine graphene has also shown that it can induce apoptosis through the the MAPK and TGF-beta signaling pathway in the macrophage cells RAW 264.7 [39]. From the current study, autoclaved MRGO treated cells showed an increase in early apoptotic (Annexin $\mathrm{V}$ positive) and late apoptotic/necrotic (double positive) cells which followed a dose dependent trend. However, there was not any enormous increase in apoptosis. This led to believe that the decrease in activity of the cells might actually be the result of delayed cell cycle progression. To affirm that, spleenic lymphocyte proliferation capacity, post treatment with autoclaved MRGO, was assessed. It is known that carbon nanotubes induce cell cycle arrest at G1 phase [38]. Autoclaved MRGO was found to reduce the proliferation of spleenic lymphocyte in a concentration dependent manner in the present study. This is in correlation with the above MTT results in L929 cells, suggesting that autoclaved MRGO did, in fact, hinder proliferation of the cells. Cell cycle arrest normally occurs when there is DNA damage. Chromosome abnormalities are a consequence of DNA damage resulting from DNA strand breaks, mis-repair of damaged DNA and so on [40]. This can occur either by direct physical interaction of a genotoxic substance with DNA or indirectly by increasing free radicals which will attack the DNA [41]. Akhavan et al. [42] studied the genotoxic potential of reduced graphene oxide nanoplatelets in human mesenchymal stem cells (hMSCs) and found out that some genotoxicity was exhibited at low concentrations but were not remarkably significant, even at the highest dose $(100 \mu \mathrm{g} / \mathrm{ml})$. Even though, in this study, chromatid breaks were seen at higher dose $(600 \mu \mathrm{g} / \mathrm{ml})$, they were not significant. On the other hand, mitotic index was considerable reduced suggesting that autoclaved MRGO inhibits occurrence of mitosis by some other means. This indicates that decreased proliferation was not due to the DNA damage but some other reason. In a study by Matesanz et al. [43] 
it was shown that graphene oxide nanosheets, when internalized by the cells, co-localized with the F-actin filaments. They observed delayed cell cycle, as actin microfilaments are required to be in one piece for cell cycle progression from G1, entry into $S$ phase and mitotic division of the cells. This could also explain the results in the present study, which indicated decreased proliferation in spleenic lymphocytes and PBMNCs.

\section{Conclusion}

MRGO was synthesized by Halomonasmaura mediated reduction of GO and characterized using TEM, AFM and FTIR. It was also found that the chemistry of MRGO upon autoclaving remained unchanged. However, changes might have occurred in the spontaneously coated mauranexo polysaccharide resulting in their toxic effects. Autoclaved MRGO showed dose dependent cytotoxicity in L929 cells. This was translated in the white blood cells as well, where a decreased proliferation, ROS generation and slight apoptosis even at $100 \mu \mathrm{g} / \mathrm{ml}$ were seen. This raises a serious concern regarding the compatibility of autoclaved MRGO with the biological system for biomedical purposes. Hence a more stable biocompatible coating over MRGO must be considered for in vivo applications. Also more extensive studies are required to fully understand the proliferation pathway which is affected in cells, when treated with autoclaved MRGO.

\section{Acknowledgment}

The authors wish to express their sincere thanks to Director and Head Biomedical Technology Wing, Sree Chitra Tirunal Institute for Medical Sciences and Technology, Thiruvananthapuram for their encouragements and support for this study. The technical supports of Ms. Leiji Babu, Ms. Anjumohan, Mr. Shaji S, Mr. Harikumar and Mr. Renjith Kartha (FACS analysis) is gratefully acknowledged.

\section{References}

1. Service RF (2003) American Chemical Society meeting. Nanomaterials show signs of toxicity. Science 300: 243.

2. Novoselov KS, Geim AK, Morozov SV, Jiang D, Zhang Y, et al. (2004) Electric field effect in atomically thin carbon films. Science 306 : 666-669.

3. Neto AHC, Guinea F, Peres NMR, Novoselov KS. Geim AK (2009) The electronic properties of graphene. Rev Mod Phys 81:109-162.

4. Novoselov KS, Morozov SV, Mohinddin TMG, Ponomarenko LA, Elias DC, et al. (2007) Electronic properties of graphene. Phys stat sol (b) 244: 4106-4111.

5. Jiang JW, Wang JS, Li B (2009) Young's modulus of Graphene: a molecular dynamics study. Phys Rev B 80: 3405-3409.

6. Balandin AA, Ghosh S, Bao W, Calizo I, Teweldebrhan D, et al. (2008) Superior thermal conductivity of single-layer graphene. Nano Lett 8: 902-907.

7. Falkovsky LA (2008) Optical properties of graphene. J PhysConfSer 129 012004.

8. Prezzi D, Varsano D, Ruini A, Marini A, Molinari E (2008) Optical properties of graphenenanoribbons: The role of many-body effects. Phys Rev B 77 : R041404.

9. Choi W, Lahiri I, Seelaboyina R, Kang YS (2010) Synthesis of Graphene and Its Applications: A Review. Cr Rev Sol State 35: 52-71.

10. Shen H, Zhang L, Liu M, Zhang Z (2012) Biomedical applications of graphene. Theranostics 2: 283-294.

11. Yang K, Zhang S, Zhang G, Sun X, Lee ST, et al. (2010) Graphene in mice: ultrahigh in vivotumor uptake and efficient photothermal therapy. Nano Lett 10: 3318-3323.

12. Sanchez VC, Jachak A, Hurt RH, Kane AB (2012) Biological interactions of graphene-family nanomaterials: an interdisciplinary review. Chem Res Toxicol 25: $15-34$.

13. Kim KM, Kim PK, Kwon YG, Bai SK, Nam WD, et al. (2002) Regulation of apoptosis by nitrosative stress. J BiochemMolBiol 35: 127-133.
14. Li N, Zhang Q, Gao S, Song Q, Huang R, et al. (2013) Three dimensiona graphene foam as a biocompatible and conductive scaffold for neural stem cells. Nature Scientific reports 3: 1-6.

15. Zhang X, Li M, Wang YB, Cheng Y, Zheng YF, et al. (2014) Cell response of nanographene platelets to human osteoblast-like MG63 cells. J Biomed Mater Res A 102: 732-742.

16. Zhang Y, Ali SF, Dervishi E, Xu Y, Li Z, et al. (2010) Cytotoxicity effects of graphene and single-wall carbon nanotubes in neural phaeochromocytomaderived PC12 cells. ACS Nano 4: 3181-3186.

17. Liao KH, Lin YS, Macosko CW, Haynes CL (2011) Cytotoxicity of graphene oxide and graphene in human erythrocytes and skin fibroblasts. ACS App Mater Interfaces 3: 2607-2615.

18. Raveendran S, Chauhan N, Nakajima $\mathrm{Y}$, Toshiaki $\mathrm{H}$, Kurosu $\mathrm{S}$, et al (2013) Ecofriendly route for synthesis of highly conductive graphene using extremophiles for green electronics and bioscience. Particle \& Particle System Characterization 30: 573-578.

19. Arias S, del Moral A, Ferrer MR, Tallon R, Quesada E, et al. (2003) Mauran, an exopolysaccharide produced by the halophilic bacterium Halomonasmaura, with a novel composition and interesting properties for biotechnology. Extremophiles 7: 319-326.

20. Hummers WS, Offeman RE (1958) Preparation of Graphitic Oxide. J Am ChemSoc 80: 1339

21. Raveendran S, Poulose AC, Yoshida Y, Maekawa T, Kumar DS (2013) Bacterial exopolysaccharide based nanoparticles for sustained drug delivery, cancer chemotherapy and bioimaging. CarbohydrPolym 91: 22-32.

22. Mosmann T (1983) Rapid colorimetric assay for cellular growth and survival: application to proliferation and cytotoxicity assays. J Immunol Methods 65: 5563.

23. Slater TF, Sawyer B, Straeuli U (1963) Studies on succinatetetrazoliumreductase systems. III. Points of coupling of four different tetrazolium salts. BiochimBiophysActa 77: 383-393.

24. Benedetti S, Catalani S, Palma F, Canestrari F (2011) The antioxidant protection of CELLFOOD against oxidative damage in vitro. Food ChemToxico 49: 2292-2298

25. Sun J, Zhang X, Broderick M, Fein H (2003) Measurement of Nitric Oxide Production in Biological Systems by Using Griess Reaction Assay. Sensors 3: $276-284$.

26. Vijayalakshmi P, Geetha CS, Mohanan PV (2013) Assessment of oxidative stress and chromosomal aberration inducing potential of three medical grade silicone polymer materials. J BiomaterAppl 27: 763-772.

27. Xia T, Kovochich M, Brant J, Hotze M, Sempf J, et al. (2006) Comparison of the abilities of ambient and manufactured nanoparticles to induce cellular toxicity according to an oxidative stress paradigm. Nano Lett 6: 1794-1807.

28. Xia T, Kovochich M, Liong M, Mädler L, Gilbert B, et al. (2008) Comparison of the mechanism of toxicity of zinc oxide and cerium oxide nanoparticles based on dissolution and oxidative stress properties. ACS Nano 2: 2121-2134.

29. Park EJ, Yi J, Chung KH, Ryu DY, Choi J, et al. (2008) Oxidative stress and apoptosis induced by titanium dioxide nanoparticles in cultured BEAS-2B cells. ToxicolLett 180: 222-229

30. Oberdörster G, Maynard A, Donaldson K, Castranova V, Fitzpatrick J, et al (2005) A report from the ILSI Research Foundation/Risk Science Institute Nanomaterial Toxicity Screening Working Group. Principles for characterizing the potential human health effects from exposure to nanomaterials: elements of a screening strategy. Part Fibre Toxicol 2: 8.

31. Sies H (1997) Oxidative stress: oxidants and antioxidants. ExpPhysiol 82: 291 295

32. Kim KM, Kim PK, Kwon YG, Bai SK, Nam WD, et al. (2002) Regulation of apoptosis by nitrosative stress. J BiochemMolBiol 35: 127-133.

33. Chang Y, Yang ST, Liu JH, Dong E, Wang Y, et al. (2011) In vitro toxicity evaluation of graphene oxide on A549 cells. ToxicolLett 200: 201-210.

34. Horvath L, Magrez A, Burghard M, Kern K, et al. (2013) Evaluation of the toxicity of graphene derivatives on cells of the lung luminal surface. Carbon 64: 45-60.

35. Simon HU, Haj-Yehia A, Levi-Schaffer F (2000) Role of reactive oxygen species (ROS) in apoptosis induction. Apoptosis 5: 415-418. 
Citation: Cherian RS, Sreejith R, Syama S, Sruthi S, Gayathri V, et al. (2014) Evaluation of Toxicity of Maura Reduced Graphene Oxide using In vitro Systems. J Nanomed Nanotechnol 5: 200. doi:10.4172/2157-7439.1000200

36. Zamzami N, Marchetti P, Castedo M, Decaudin D, Macho A, et al. (1995) Sequential reduction of mitochondrial transmembrane potential and generation of reactive oxygen species in early programmed cell death. J Exp Med 182: 367-377.

37. Bottini M1, Bruckner S, Nika K, Bottini N, Bellucci S, et al. (2006) Multi-walled carbon nanotubes induce T lymphocyte apoptosis. ToxicolLett 160: 121-126.

38. Cui D1, Tian F, Ozkan CS, Wang M, Gao H (2005) Effect of single wall carbon nanotubes on human HEK293 cells. ToxicolLett 155: 73-85.

39. Li Y, Liu Y, Fu Y, Wei T, Le Guyader L, et al. (2012) The triggering of apoptosis in macrophages by pristine graphene through the MAPK and TGF-beta signaling pathways. Biomaterials 33: 402-411.
40. AshaRani PV, Low Kah Mun G, Hande MP, Valiyaveettil S (2009) Cytotoxicity and genotoxicity of silver nanoparticles in human cells. ACS Nano 3: 279-290.

41. vanBerlo D, Clift MJ, Albrecht C, Schins RP (2012) Carbon nanotubes: an insight into the mechanisms of their potential genotoxicity. Swiss Med Wkly 142: w13698.

42. Akhavan O, Ghaderi E, Akhavan A (2012) Size-dependent genotoxicity of graphenenanoplatelets in human stem cells. Biomaterials 33: 8017-8025.

43. Matesanz MC, Vila M, Feito MJ, Linares J, Gonçalves G, et al. (2013) The effects of graphene oxide nanosheets localized on F-actin filaments on cellcycle alterations. Biomaterials 34: 1562-1569. 